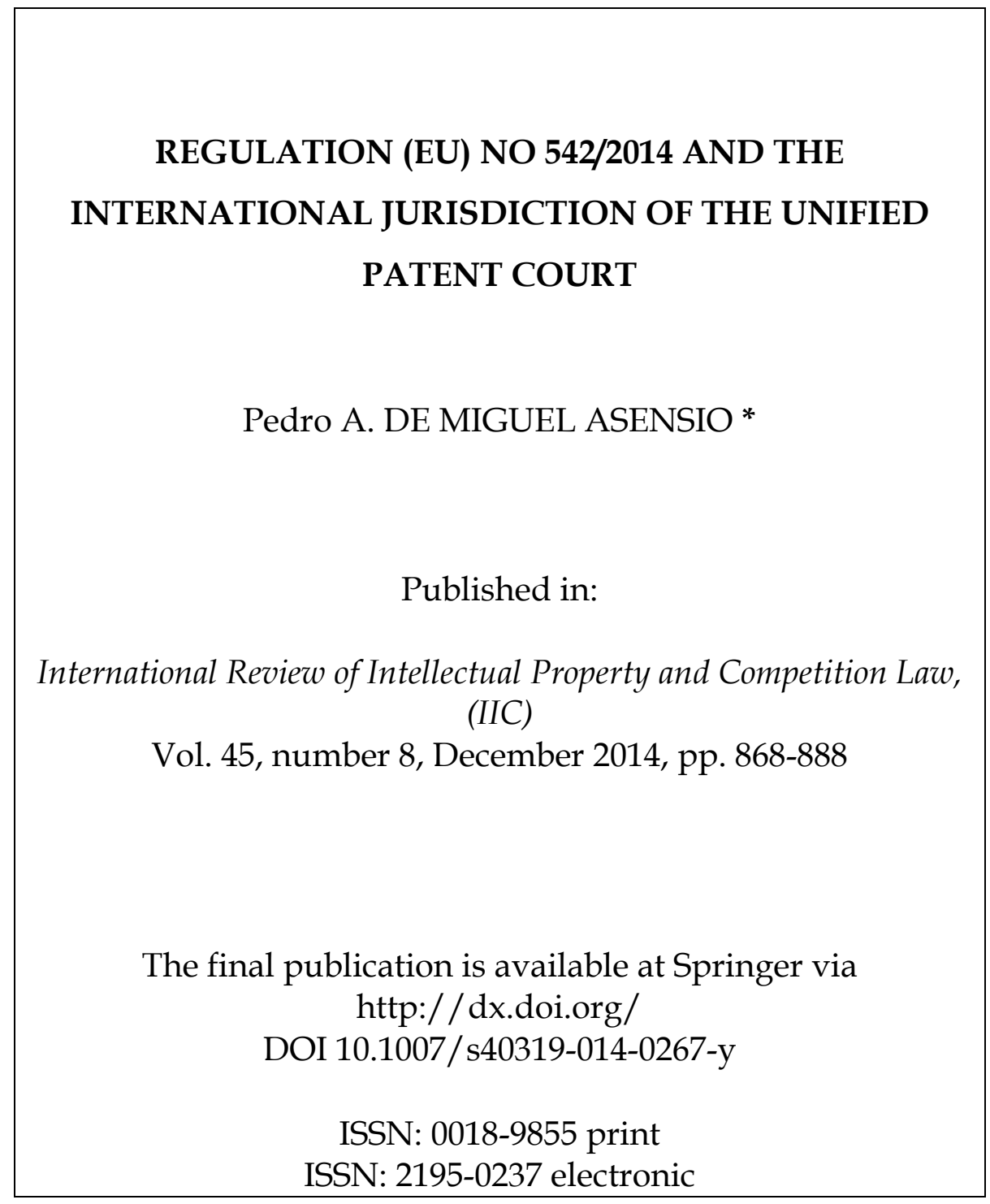

* Catedrático de Derecho internacional privado

Facultad de Derecho

Universidad Complutense de Madrid

E- 28040 MADRID

pdmigue@ucm.es 


\section{ABSTRACT}

Regulation (EU) No 542/2014 amends the Brussels I bis Regulation and establishes rules which govern, among other issues, the international jurisdiction of the Unified Patent Court (UPC), and the recognition and enforcement of judgments given by the UPC in Members States of the Regulation which are not Contracting Parties to the UPC Agreement. Particular attention deserves the new supplementary forum that enables the UPC to hear disputes involving defendants from third States that relate to an infringement of a European patent giving rise to damage as well inside as outside the Union. Granting jurisdiction to the UPC to adjudicate infringements outside the territory of the Contracting States to the UPC Agreement on the basis of an asset-related supplementary ground of jurisdiction as the one established under the new Regulation seems questionable.

\section{KEYWORDS:}

Patents, Unified Court, International Jurisdiction, Recognition and Enforcement of Judgments. 


\title{
Regulation (EU) No 542/2014 and the International Jurisdiction of the Unified Patent Court
}

\author{
Pedro A. De Miguel Asensio*
}

\section{Introductory remarks}

The adoption of Regulation (EU) No 542/2014 ${ }^{1}$ amending Regulation (EU) No 1215/2012 or Brussels I bis Regulation ${ }^{2}$ has been regarded as a necessary step prior to the functioning of the Unified Patent Court (UPC). The legislative process reviewing a recent Regulation, such as the Brussels I bis Regulation, whose rules are not yet applicable, was initiated by the Commission Proposal of 26 July $2013^{3}$. Although the scope of the reform finally adopted does not deviate from the Commission proposal, some problematic aspects of the initial text have been attenuated. Notwithstanding this, certain elements of Regulation (EU) No 542/2014 may still raise concerns. The present article aims at providing a general overview of the reform and a critical analysis of several of its provisions ${ }^{4}$.

After considering the characterization of the UPC and its relationship with the Brussels I bis Regulation (II, infra), three main issues will be discussed: scope of the reform of the Brussels I bis Regulation (III, infra); international jurisdiction of the UPC, including a critical assessment of the new supplementary forum based on the location of

* Professor at the Law Faculty of the Complutense University of Madrid. All webpages cited have been last accessed on 4 June 2014. Research project DER 2012-34086 (MEC).

${ }^{1}$ Regulation (EU) No 542/2014 of the European Parliament and of the Council of 15 May 2014 amending Regulation (EU) No 1215/2012 as regards the rules to be applied with respect to the Unified Patent Court and the Benelux Court of Justice, OJ 2014 L 163, p. 1.

${ }^{2}$ Regulation (EU) No 1215/2012 of 12 December 2012 on jurisdiction and the recognition and enforcement of judgments in civil and commercial matters (recast), OJ 2012 L 351, p.1.

${ }^{3} \mathrm{COM}(2013) 554$ final.

${ }^{4}$ This article is based on a previous study discussing the Commission proposal and the Council amendments, see Pedro A. De Miguel Asensio, "The Unified Patent Court Agreement and the Amendment to the Brussels I Regulation (Recast)", in Costanza Honorati (ed.), Luci e ombre del nuovo sistema UE di tutela brevettuale (The EU Patent Protection - Lights and Shades of the New System), Torino, G. Giappichelli Editore, 2014, pp. 153-170. 
property of the defendant (IV, infra); and recognition and enforcement of judgments (V, infra).

\section{The Unified Patent Court: exclusive competences and international jurisdiction}

Regarding the foundations of Regulation (EU) No 542/2014, it is noteworthy that article 89 of the Agreement on a Unified Patent Court (UPC Agreement) ${ }^{5}$ makes the entry into force of the Agreement dependent upon, among other conditions, the entry into force of the amendments to the Brussels I bis Regulation concerning its relationship with the Agreement. Regulation (EU) No 542/2014 shall apply from 10 January 2015 (art. 2). This date has been chosen to ensure the coordination between the new Regulation and the reform process of the Brussels I bis Regulation. Pursuant to article 81 Regulation 1215/2012, the provisions of the Brussels I bis Regulation prior to the amendments shall also apply from 10 January 2015, replacing Regulation (EC) No $44 / 2001^{6}$ from that date.

The UPC Agreement is aimed at establishing a unified court «for the settlement of disputes relating to European patents and European patents with unitary effect» (article 1), that shall replace the national courts of the Contracting Members States for the disputes falling within its exclusive competence ${ }^{7}$. The UPC is a court common to the Contracting Member States and subject to EU law as any national court (article 1 of the UPC Agreement), but not all EU Member States participate in the UPC Agreement. In particular, Spain, Poland and Croatia have not signed the Agreement, while most of the signatories are yet in the process of ratification ${ }^{8}$. Article $89(1)$ requires only the ratification or accession by thirteen Member States (including Germany, France and the

${ }^{5}$ OJ 2013 C 175, p. 1.

${ }^{6}$ OJ 2001 L 12, p.1.

${ }^{7}$ Manuel Desantes Real, "Le «paquet europeen des brevets», paradigme du chemin à rebours: de la logique institutionnelle à la logique intergouvernamentale", Cahiers de droit européen, vol. 49, 2013, pp. 577-670, pp. 651-670; and id. "Hacia un Tribunal unificado y un efecto unitario para las patentes europeas en casi todos los Estados miembros de la Unión Europea. Consecuencias de la autoexclusión de España”, in Revista Española de Derecho Internacional, vol. 49, 2013(2), p. 51-70. For a critical view of the proposals that preceded the adoption of the final text of the Agreement, see Thomas Jaeger, "All Back to Square One? - An Assessment of the Latest Proposals for a Patent and Court for the Internal Market and Possible Alternatives", IIC, vol. 43, 2012, pp. 286-308; and Fernand de Visscher, "European Unified Patent Court: Another More Realistic and More Equitable Approach Should Be Examined", GRUR Int., vol. 61, 2012, 214-224.

$8<$ http://ec.europa.eu/internal_market/indprop/patent/ratification/index_en.htm> (as of 4 June 2014 only Austria and France have ratified the UPC Agreement). 
United Kingdom) as one of the conditions for the entry into force of the Agreement, and article 83 UPC Agreement establishes special provisions for the transitional period.

As to the competence of the $\mathrm{UPC}^{9}$, the Agreement lays down the actions relating to European patents and European patents with unitary effect that fall within the exclusive competence of the common court and that hence should be excluded from the competence of national courts of the Contracting Member States. Article 32 of the Agreement grants exclusive competence to the UPC in respect of, among others, actions for actual or threatened infringements; actions for declarations of non-infringement; actions for provisional and protective measures and injunctions; actions and counterclaims for revocation of patents and for declaration of invalidity of supplementary protection certificates; actions for damages or compensation derived from the provisional protection conferred by a published European patent application; actions relating to the use of the invention prior to the granting of the patent or to the right based on prior use of the invention... National courts remain competent for actions relating to patents and supplementary protection certificates which do not come within the exclusive competence of the UPC (article 32.2 of the UPC Agreement).

Pursuant to article 83(1) UPC Agreement, during a transitional period of seven years after the date of entry into force of the Agreement, an action for infringement or for revocation of a European patent may still be brought before national courts or authorities ${ }^{10}$. Additionally, unless an action has already been brought before the UPC, article 83(3) gives a proprietor of or an applicant for a European patent granted or applied for prior to the end of the seven-year transitional period, the possibility to opt out from the exclusive competence of the UPC. During the transitional period patentees can choose, patent by patent, whether they enforce in the UPC or whether they opt out of it and continue to litigate in national courts. The opt-out has to be notified to the Registry of the Court by the latest one month before expiry of the transitional period ${ }^{11}$.

Therefore the UPC Agreement provides for the distribution of competences between the UPC and the national courts of the Contracting Member States. By contrast the

\footnotetext{
9 Matthias Brandi-Dohrn, "Some Critical Observations on Competence and Procedure of the Unified Patent Court", IIC, vol. 43, 2012, pp. 372-389.

${ }^{10}$ Mark Bosshard, 'L'entrata in vigore del pacchetto sul brevetto unitario: il regime transitorio e la dichiarazione di opt out", in Costanza Honorati (ed.), Luci... cit., pp. 203-230.

${ }^{11}$ Massimo Scuffi, "Il Tribunale unificato dei brevetti: evoluzione storica, ordinamento e regole Procedimentali”, in Costanza Honorati (ed.), Luci... cit., pp. 73-100.
} 
Agreement does not regulate the international jurisdiction of the $\mathrm{UPC}^{12}$. Since the rules on international jurisdiction and recognition and enforcement of judgments concerning the disputes falling within the competence of the UPC had previously been unified within the EU -and the EU had also concluded a parallel international convention covering such disputes ${ }^{13}$-, the UPC Agreement does not lay down its own rules on international jurisdiction. Furthermore, under article 71 of Regulation No 44/2001, Member States are prevented from concluding any new conventions that, in relation to particular matters, govern jurisdiction or the recognition or enforcement of judgments. Hence, pursuant to article 31 of the UPC Agreement, the international jurisdiction of the UPC is to be established in accordance with Regulation (EU) No 1215/2012 or, where applicable, on the basis of the Lugano Convention ${ }^{14}$. In order to ensure the proper coordination between the Brussels I bis Regulation and the UPC Agreement, the latter assumed that certain amendments were needed in Regulation (EU) No 1215/2012, as it was made explicit in article 89 UPC Agreement. The basic goal of the newly adopted Regulation (EU) No 542/2014 is to adapt the Brussels I bis Regulation and guarantee its coordination with the UPC Agreement.

\section{Issues addressed by Regulation (EU) no 542/2014}

The adoption on 6 May 2014 of Regulation (EU) $n^{0} 542 / 2014$ was the final step of the legislative process launched with the Commission Proposal of 26 July 2013. On 6 December 2013 at the Justice Council, the Ministers agreed on a general approach ${ }^{15}$ "in record time" ${ }^{\prime 16}$. The European Parliament's Legal Affairs Committee voted on 11

12 The Rules of the UPC that are to be adopted by the Administrative Committee (article 41 UPC Agreement) shall be of great practical importance with respect to the procedure of the court and the organization of the proceedings but can not include provisions on international jurisdiction; see "Preliminary set of provisions for the Rules of Procedure ("Rules") of the Unified Patent Court", 16th Draft of 31 January 2014, <http://www.unified-patent-court.org/news/72-revised-16th-draft-of-the-rulesof-procedure $>$. See Marina Tavassi, "Le Rules of Procedure e i rapporti tra Tribunale unificato e giudice nazionale", in Costanza Honorati (ed.), Luci... cit., pp. 183-202.

13 Klaus Grabinski, "Zur Bedeutung des Europäischen Gerichtsstands- und Vollstreckungsübereinkommens (Brüsseler Übereinkommens) und des Lugano-Übereinkommens in Rechtsstreitigkeiten über Patentverletzungen“, GRUR Int, vol. 50, 2001, pp. 199-211.

${ }^{14}$ Convention on jurisdiction and the recognition and enforcement of judgments in civil and commercial matters, done at Lugano on 30 October 2007, OJ 2007 L 339, p. 3.

${ }^{15}$ Council of the European Union, 16982/13 ADD 1, JUSTCIV 290 PI 176 CODEC 2754, of 29 November 2013.

${ }^{16}$ European Commission - MEMO/13/1109, 06/12/2013. 
February 2014 in favour of the compromise text agreed with the Commission and the Council. The plenary vote at the Parliament took place on 15 April 2014. Although the Regulation was expected to be formally adopted by the Council in June ${ }^{17}$, it was adopted at the meeting of the Economic and Financial Affairs Council on 6 May $2014{ }^{18}$.

As stated in the Explanatory Memorandum of the Commission proposal, Regulation (EU) $n^{\circ}$ 542/2014 amending Regulation (EU) No 1215/2012 covers several issues deemed necessary to ensure the combined and coherent application of the Brussels I bis Regulation, the UPC Agreement and a Protocol of 2012 to the Treaty establishing a Benelux Court of Justice, which is a court common to the Benelux countries having jurisdiction over certain subject matters such as intellectual property. This Protocol falls outside the scope of this contribution and hence the specific issues concerning the Benelux Court of Justice will not be discussed here.

Pursuant to the new Regulation four new articles are inserted in the Brussels I bis Regulation, articles 71(a), 71(b), 71(c) and 71(d). The new article 71(a) clarifies in the text of the Regulation that the UPC is a 'court' within the meaning of the Brussels I bis Regulation. Since the UPC replaces national courts for certain disputes and the Brussels I bis Regulation does not include a complete set of rules on international jurisdiction vis-à-vis defendants domiciled in third States, but merely refers to national laws (article 6), the reform establishes in article 71(b) uniform rules with respect to international jurisdiction in proceedings against such defendants brought in the UPC.

Recital 5 of Regulation (EU) No 542/2014 highlights that the amendments to the Brussels I bis Regulation that it provides for only deal with the international jurisdiction of the UPC and do not affect the internal allocation of proceedings among the divisions of the UPC nor the arrangements concerning the exercise of jurisdiction during the transitional period foreseen in the UPC Agreement. In particular, article 33 of the UPC Agreement regulates the competence of the divisions of the Court of First Instance. Although the coordination between the rules granting international jurisdiction to the UPC and the provisions on the internal allocation of competence within the UPC may

\footnotetext{
${ }^{17}$ European Commission - MEMO/14/308, 15/04/2014.

${ }^{18}$ Council of the European Union - 9356/14 PRESSE 251, 06/05/2014.
} 
raise difficulties ${ }^{19}$, the application of the latter falls beyond the scope of the Brussels I bis Regulation and hence is not dealt with in its amendment.

Additionally, the new article 71(c) deals with the application of the rules on lis pendens and related actions of the Brussels I bis Regulation when proceedings are brought before the UPC and a court of a Member State to which the UPC Agreement does not apply. Article 71(c) establishes that the rules on lis pendens and related actions of the Brussels I bis Regulation apply between the UPC and the courts of nonContracting Member States (and the national courts of a Member State party to the UPC Agreement during the transitional period). Therefore, the amendment does not review the provisions of Articles 29 to 32 of the Brussels I bis Regulation. It merely extends their application to cover proceedings brought in the UPC. ${ }^{20}$

It is clear that the new Article 71(c) does not apply to similar situations that may arise within the UPC, such as cases where an action between the same parties on the same patent is brought before several different divisions of the UPC. Those issues are dealt with by the provisions regulating the UPC, such as article 33(2) UPC Agreement.

Regulation (EU) $n^{\circ} 542 / 2014$ does not contain any provisions on the coordination between proceedings brought in the UPC and proceedings that are pending before a court of a third State. In this respect, Regulation (EU) 1215/2012 introduced in articles 33 and 34 flexible mechanisms enabling the coordination between proceedings brought in the courts of a Member State and proceedings pending in the courts of third States. Under these mechanisms a court of a Member State may stay its proceedings, considering in particular whether a judgment of a third State will be capable of recognition and enforcement in the Member State concerned and if the stay is necessary for the proper administration of justice. Since the UPC is deemed to be a court of a Member State, articles 33 and 34 Brussels I bis Regulation may be applicable to situations in which the jurisdiction of the UPC is based on Articles 4 or on Articles 7 or 8 of the Brussels I bis Regulation.

Finally, article 71(d) is aimed at ensuring that the provisions of the Brussels I bis Regulation govern also the recognition and enforcement of judgments given by the UPC in Members States which are not Contracting Parties to the UPC Agreement .

\footnotetext{
19 Manuel Desantes Real, "Le «paquet..., cit., p. 663.

${ }^{20}$ Pedro A. De Miguel Asensio, "The Unified..., cit., at pp. 165-167.
} 
The amendment of the Brussels I bis Regulation stating expressly that the UPC is to be considered a 'court of a Member State' -article 71(a)- within the meaning of the Regulation is basically intended to provide predictability to defendants that as a result of the internal allocation of proceedings within the UPC may be sued at a location different from the Member State designated by the Regulation. The internal distribution of competences among the divisions of the UPC may lead to situations where a defendant is sued in the courts of its own domicile on the basis of article 4 Brussels I bis Regulation before a division of the UPC that is really located in another Contracting State. Such a possibility also affects defendants domiciled in Member States - or in States parties to the Lugano Convention - that are not Contracting Parties to the UPC Agreement when they are sued before the UPC on the basis of other jurisdiction rules, such as «the place where the harmful event occurred or may occur»-article 7(2) of the Brussels I bis Regulation- or the place of performance of a contractual obligation article 7(1). According to the Commission's view, expressed in the Explanatory Memorandum to the Proposal, «legal certainty and predictability for defendants requires that this change of territorial jurisdiction is set out clearly in the text of the Brussels I Regulation ${ }^{21}$. Therefore, a specific legislative amendment establishing that a court common to several Member States such as the UPC is a 'court' of a Member State for the purposes of the Brussels I bis Regulation was deemed necessary, and may now be found in the new article 71(a).

Apart from possible concerns as to the effectiveness of the method used to properly safeguard the defendants' interests, doubts may arise as to the coordination between the UPC Agreement and the 2007 Lugano Convention in the absence of an amendment to the Convention. The Lugano Convention does not prejudice the application between the Member States of the EU of the Brussels I Regulation as well as any amendments thereof - article 64(1) of the Lugano Convention.

Furthermore, by contrast with the Brussels I Regulation, the Lugano Convention does not prevent Contracting Parties from entering into new conventions which in relation to particular matters govern jurisdiction or the recognition and enforcement of judgments - article $67(1)$ of the Lugano Convention. Notwithstanding this, the UPC Agreement cannot be regarded as a Convention within the meaning article 67(1) of the

\footnotetext{
${ }^{21} \operatorname{COM}(2013) 554$ final, p. 5.
} 
Lugano Convention, and pursuant to article 71 of Regulation 44/2001 Member States of the Brussels I Regulation are prevented from concluding such conventions. Hence, as already noted the UPC Agreement lacks rules on international jurisdiction and recognition and enforcement of judgments.

In accordance with article 31 of the UPC Agreement, the Lugano Convention is to be applied by the UPC in matters of jurisdiction, particularly, where the defendant is domiciled in the territory of a State where the Lugano Convention but not the Brussels I bis Regulation applies, or where articles 22 (exclusive jurisdiction) or 23 (prorogation of jurisdiction) of the Lugano Convention are applicable. Therefore, in the light of the Commission's view that the clarification in the Brussels I bis Regulation that the UPC is a 'court' of a Member State is essential to ensure legal certainty and predictability for defendants with respect to the granting of jurisdiction to the UPC, concerns may arise as to the application by the UPC of the jurisdiction rules of the Lugano Convention. Indeed, with respect to defendants domiciled in the territory of a State where the Lugano Convention but not the Brussels I bis Regulation applies (Iceland, Norway and Switzerland), the possibility to be sued before the UPC at a location situated in a Member State other than the one designated by the rules of the Lugano Convention, such as «the place where the harmful event occurred or may occur» - article 5 (3) - or the place of performance of the contractual obligation - article 5(1) -, as a result of the internal allocation of competences within the UPC, could undermine legal certainty and predictability, in the absence of a similar clarification in the text of the Lugano Convention, establishing that the UPC will have jurisdiction any time when a national court of one of its Contracting Member States would have jurisdiction based on the rules of the Lugano Convention.

From the perspective of the evolution of the judicial cooperation in civil matters within the EU, it is remarkable that Regulation (EU) 542/2014 regulates international jurisdiction in disputes involving defendants domiciled outside the EU for matters which fall within the competence of the UPC. However, the scope of the amendment to the Regulation is very limited, since the uniform regime inserted with respect to defendants domiciled in third countries only applies to the jurisdiction of the UPC. The preservation of different rules governing access to justice in the Member States with respect to disputes involving third State defendants in the matters covered by the 
Brussels I bis Regulation remains a significant failure in the evolution of the Regulation, that creates significant distortions between the jurisdiction rules and the provisions on recognition and enforcement of judgments of the Regulation.

\section{Jurisdiction over defendants not domiciled in a Member State}

\section{General overview of the jurisdiction rules after Regulation (UE) $n^{\circ} 542 / 2014$}

Regarding the international jurisdiction of the UPC, the starting point is the new article 71(b)(1) inserted in the Brussels I bis Regulation. According to that provision, jurisdiction is granted to the UPC where, under the Brussels I bis Regulation, the courts of a Member State party to the UPC Agreement would have jurisdiction in a matter governed by the Agreement. This provision is in line with the reference made by article 31 of the UPC Agreement to Regulation No 1215/2012. The bases of jurisdiction established in the Brussels I bis Regulation ${ }^{22}$, such as the exclusive jurisdiction of article 24(4), the jurisdiction founded on agreement (article 25) the general jurisdiction of the defendant's domicile (article 4), the special jurisdiction under articles 7 and 8 and the submission to jurisdiction (article 26) also apply with respect to the UPC. In practice, the scope of the exclusive jurisdiction rule of article 24(4) Brussels I bis Regulation -article 22(4) Lugano Convention- that applies irrespective of whether the validity or registration issue is raised by way of an action or as a defence may bar the UPC in many cases from adjudicating claims concerning infringements in the territory of Member States of those instruments that are not Contracting Parties to the UPC Agreement.

Furthermore, the new article 71(b)(2) and (3) amend the Brussels I bis Regulation with respect to the international jurisdiction of the UPC in disputes involving defendants not domiciled in a Member State. Due to their particular scope of application, these provisions will not be relevant vis-à-vis defendants domiciled in the EU - even if domiciled in a Member State that is not a Contracting Party to the UPC -

22 James J. Fawcett and Paul Torremans, Intellectual Property and Private International Law, 2nd., ed., Oxford, OUP, esp. pp. 143-192 and pp. 341-393; for a previous analysis discussing the application of the Brussels Convention in the field of patents, see Pierre Véron, "Thirty Years of Experience with the Brussels Convention in Patent Infringement Litigation”, 84 J. Pat. \& Trademark Off. Soc', 431 (2002), pp. 431-455. 
or in Iceland, Norway and Switzerland, to the extent that the Lugano Convention applies.

Article 71(b)(2) extends the jurisdiction rules of the Brussels I bis Regulation to third State defendants. It establishes that where the defendant is not domiciled in a Member State, and the Regulation does not otherwise confer jurisdiction over him - for instance, based on the exclusive jurisdiction laid down in article 24(4) in proceedings concerned with the registration or validity of patents or on the basis of article 25 on prorogation of jurisdiction -, the provisions of Chapter II apply regardless of the defendant's domicile. Chapter II of the Brussels I bis Regulation includes the bases of jurisdiction, such as those established in the special provisions of articles 7 and 8 and the submission to jurisdiction (article 26). Furthermore, article 71(b)(2) envisages the possibility to apply to the UPC for provisional, including protective, measures allowed for in article 35 of the Regulation in connection to third State defendants even if the courts of a third State have jurisdiction as to the substance of the matter. Finally, article 71(b)(3) supplements the fora of the Regulation by establishing an additional ground of jurisdiction.

The scope of the jurisdiction of the UPC with respect to patent disputes concerning States that do not participate in the UPC Agreement raises further considerations that are not addressed in Regulation (EU) $n^{0} 542 / 2014$. Paradoxically, the implementation of the UPC Agreement seems to lead in this respect to some additional fragmentation concerning cross-border litigation of patent disputes ${ }^{23}$. Since the UPC is established «for the settlement of disputes relating to European patents and European patents with unitary effect» (article 1 of the UPC Agreement), the issue arises as to the treatment of those situations in which the courts of a Member State, pursuant to the Brussels I bis Regulation (for instance, as a result of the general jurisdiction based on the defendant's domicile), have jurisdiction to adjudicate not only claims concerning the infringement by the defendant of a European patent but also the infringement by the

${ }^{23}$ Regarding the fragmentation of jurisprudence as one of the problems raised by the unitary patent, see, from a different perspective, Max Planck Institute for Intellectual Property and Competition Law (Reto M. Hilty, Thomas Jaeger, Matthias Lamping and Hanns Ullrich), "The Unitary Patent Package: Twelve Reasons for Concern" (October 17, 2012), <http://www.ip.mpg.de/files/pdf2/MPIIP_Twelve-Reasons_2012-10-17_final3.pdf >. 
defendant of patents granted in non-European States $^{24}$ that fall outside the scope of the UPC. The national courts of the Contracting Member States to the UPC remain competent with respect to claims that do not concern European patents, to the extent that jurisdiction is granted to them under the Brussels I bis Regulation, Lugano Convention or national legislation pursuant to article 6 of the Brussels I bis Regulation.

Furthermore, the national courts of the Contracting Member States remain competent for actions relating to patents and supplementary protection certificates which do not fall within the exclusive competence of the Court (article 32 of the UPC Agreement).

\section{The supplementary jurisdiction rule in the Commission Proposal}

The insertion in article 71(b)(3) Brussels I bis Regulation of a supplementary rule granting jurisdiction to the UPC based on the location of property in a Contracting Member State to the UPC Agreement deserves particular attention. This provision evolved significantly during the legislative process. A reference to the Commission proposal is necessary to assess that evolution and the rationale of the new provision.

According to the wording of article 71(b)(3) in the Commission Proposal, the UPC would have jurisdiction if: «a) property belonging to the defendant is located in a Member State party to the agreement establishing the common court; b) the value of the property is not insignificant compared to the value of the claim; c) the dispute has a sufficient connection with any Member State party to the agreement establishing the common court». The reasons provided by the Commission in favour of the addition of this subsidiary ground of jurisdiction were the following:

«The proposal provides that a non-EU defendant can be sued at the place where moveable assets belonging to him are located provided their value is not insignificant compared to the value of the claim and that the dispute has a sufficient connection with the Member State of the court seized. The forum of the location of assets balances the absence of the defendant in the Union. Such a rule currently exists in a sizeable group of Member States and has the advantage of ensuring that a judgment can be enforced in

${ }^{24}$ See Dário Moura Vicente, La propriété intellectuelle en droit international privé, in Rec. des cours, vol. 335 (2008), p. 105-503, at pp. 384-389; Marko Schauwecker, Extraterritoriale Patentverletzungsjurisdiktion: Die internationale Zuständigkeit der Gerichte außerhalb des Patenterteilungsstaates für Verletzungsverfahren, Köln, Heymanns, 2009; Marketa Trimble, Global Patents (Limits of Transnational Enforcement), Oxford, OUP, 2012, esp. pp. 46-47; and Benedetta Ubertazzi, Exclusive Jurisdiction in Intellectual Property, Tübingen, Mohr Siebeck, 2012. 
the State where it was issued. It is a rule which fits better in the general philosophy of the Brussels I Regulation (recast) than other rules of subsidiary jurisdiction such as those provided for in the Trademark and Design Regulations mentioned above which allow proceedings against third State defendants to be brought, in particular, before the courts of the Member State where the plaintiff is domiciled (forum actoris). An assetbased forum may ensure the jurisdiction of the Unified Patent Court and the Benelux Court of Justice in situations where the Regulation's extended jurisdiction rules would not provide for jurisdiction and where such jurisdiction may be appropriate. For instance, with respect to the Unified Patent Court, the asset-based jurisdiction would ensure that the Court would have jurisdiction vis-à-vis a Turkish defendant infringing a European patent covering several Member States and Turkey». ${ }^{25}$

Several misunderstandings seem to underlie the justification given by the Commission concerning the proposed rule. For instance, the Commission stresses that a jurisdiction rule based on the presence of defendant's assets in a Member State fits better than the fora established in the Trade Mark Regulation ${ }^{26}$ and in the Design Regulation $^{27}$, which allow proceedings to be brought before the courts of the Member State where the plaintiff is domiciled. A comparison in such terms between the proposed rule and those jurisdiction provisions of the Trade Mark and Design Regulations seems inappropriate in the light of the different functions that those rules fulfil.

It is true that the jurisdiction rules contained in the Trade Mark and Design Regulations allow proceedings to be brought in the courts of the Member State in which the plaintiff is domiciled ${ }^{28}$, but the provisions envisaged in the proposed article $71(\mathrm{~b})(3)$ would determine the extent of the jurisdiction of the UPC in situations not having a similar connection with the Contracting States to the UPC Agreement. By contrast, the rules of the Trade Mark and Design Regulations basically allocate jurisdiction to the courts of a Member State of the Regulation in situations that clearly (and on other grounds) should fall within the international jurisdiction of the EU Member States

Indeed, article 97(2) of Regulation (EC) No 207/2009 on the Community Trade Mark establishes that if the defendant is neither domiciled nor has an establishment in any of the Member States, certain proceedings shall be brought in the courts of the

\footnotetext{
${ }^{25} \operatorname{COM}(2013) 554$ final, at p. 6-7. 78 , p. 1

${ }^{26}$ Regulation (EC) No 207/2009 of 26 February 2009 on the Community trade mark, OJ 2009 L

${ }^{27}$ Regulation (EC) No 6/2002 of 12 December 2001 on Community designs, OJ 2002 L 3, p. 1.

${ }^{28}$ James J. Fawcett and Paul Torremans, Intellectual ..., cit., pp. 412-417.
} 
Member State in which the plaintiff is domiciled or in which he has an establishment. However, this provision and its alleged forum actoris have to be assessed taking into consideration that it only covers proceedings in respect of the actions and claims referred to in article 96 of the Community Trade Mark Regulation. It basically encompasses proceedings resulting from infringement actions and actions in respect of threatened infringement relating to Community trademarks; actions for declaration of non-infringement of Community trademarks; and counterclaims for revocation or for a declaration of invalidity of a Community trade mark. Since the proceedings refer to the infringement and validity of Community trade marks, it is undisputed that the courts of one or several Member States must have international jurisdiction to adjudicate such disputes, and hence the function of article 97(2) of the Community Trade Mark Regulation is essentially to allocate jurisdiction among the Member States ${ }^{29}$. By contrast, an additional forum as the one envisaged in the Commission proposal would determine the extent of the international jurisdiction of the UPC with regard to disputes involving third State defendants with respect to, for instance, the infringement of European patents outside the EU.

Such an aim of the proposed provision was also clearly acknowledged by the Commission in its justification of the rule, since it stated that the asset-based jurisdiction would ensure that the UPC «would have jurisdiction vis-à-vis a Turkish defendant infringing a European patent covering several Member States and Turkey ${ }^{30}$. If the 'Turkish defendant' is domiciled in the EU, the courts of a Member State (including the UPC) would have general jurisdiction on the basis of article 4 Brussels I bis Regulation. If a defendant domiciled in Turkey infringes a European patent in the EU, the courts of one or several Member States (including the UPC) would have jurisdiction based on article 7(2) of the Brussels I bis Regulation. Therefore, it has to be assumed that the Commission referred to the jurisdiction of the UPC to adjudicate the infringement in Turkey of a European patent validated in Turkey by a defendant domiciled in Turkey. Such an extension of the jurisdiction of the UPC on the basis of a new forum does not seem appropriate and lacked adequate justification by the Commission.

\footnotetext{
Regulation.

${ }^{29}$ A similar conclusion may be reached with respect to Article 82 of the Community Design ${ }^{30} \operatorname{COM}(2013) 554$ final, p. 7.
} 


\section{The new article 71(b)(3) Brussels I bis Regulation}

The final text of article 71(b)(3) is the result of the amendments made during the legislative process, with the participation of the Council and the Parliament. In particular, the additional jurisdiction rule experienced a significant evolution between the Commission proposal and the text agreed by the Council. The final wording in Regulation (EU) $n^{0} 542 / 2014$ of the new article 71(b)(3) is as follows:

«where a common court has jurisdiction over a defendant under point 2 in a dispute relating to an infringement of a European patent giving rise to damage within the Union, that court may also exercise jurisdiction in relation to damage arising outside the Union from such an infringement.

Such jurisdiction may only be established if property belonging to the defendant is located in any Member State party to the instrument establishing the common court and the dispute has a sufficient connection with any such Member State.»

According to its final wording, the supplementary jurisdiction would only apply where the UPC has jurisdiction under Chapter II of the Brussels I bis Regulation over a defendant not domiciled in a Member State «in a dispute relating to an infringement of a European patent giving rise to damage within the Union» (it can be argued that the reference to the Union should in practice be understood as to the territory of the EU Member States that are contracting parties to the UPC Agreement). The additional jurisdiction rule only establishes that the UPC «may also have jurisdiction in relation to damage arising outside the Union from such an infringement». Furthermore, under the final text of the provision such a supplementary jurisdiction may only be granted if property belonging to the defendant is located in a Member State party to the UPC Agreement and the dispute has a sufficient connection with such a Member State.

The scope of the provision finally adopted is more restricted than in the Commission proposal. Recital 7 of Regulation (EU) $n^{0} 542 / 2014$ expressly insists on the fact that the subsidiary rule of jurisdiction in article 71(b)(3) enables the UPC to hear disputes involving defendants from third States relating to an infringement of a European patent giving rise to damage as well inside as outside the Union. Furthermore, recital 7 provides specific guidance by referring to some of the factors that may be relevant in 
establishing that a dispute has sufficient connection with the Contracting State of the UPC Agreement where property belonging to the defendant is located as a condition to grant international jurisdiction to the UPC. In particular, as examples of relevant factors in that respect, the recital mentions the claimant's domicile in that Contracting State or the availability there of evidence relating to the dispute. Furthermore, it refers to the need to consider the value of the property in question which should be likely to make the enforcement of the judgment possible, at least in part, in that Contracting State.

\section{The forum based on the location of property: a critique}

Although the evolution of article 71(b)(3) during the legislative process is to be welcome $^{31}$, the final approach also raises concerns. As already noted, pursuant to Regulation (EU) $n^{\circ} 542 / 2014$, article 71(b)(3) is intended to be applied to proceedings against a third State defendant brought before the UPC «relating to an infringement of a European patent giving rise to damage as well inside as outside the Union». For those situations, the new provision establishes that the UPC «may also exercise jurisdiction in relation to damage arising outside the Union from such an infringement». The rationale behind the supplementary forum seems to be to enhance a key advantage that the UPC may offer to become an alternative forum to the US for major patent litigation ${ }^{32}$. Providing patentees the ability to obtain pan-European enforcement impacting on a large customer base is essential in that respect. The supplementary rule extends the reach of single enforcement to cover infringements outside the EU by defendants not domiciled in a Member State, offering the patentees the possibility to claim enforcement without having to litigate in the country of infringement.

This subsidiary rule seems intended to supplement the jurisdiction ground established in article 7(2) of the Brussels I bis Regulation that in matters relating to tort allows proceedings to be brought «in the courts for the place where the harmful event

${ }^{31}$ For a critical analysis of the Commission Proposal, see Pedro A. De Miguel Asensio, "La Propuesta de modificación del Reglamento 1215/2012 (Bruselas I bis) para su adaptación al Acuerdo sobre un Tribunal Unificado de Patentes", La Ley Unión Europea, num. 7, September 2013, p. 3-8.

${ }^{32}$ For a critical anlysis of the UPC system stressing its differences with the US federal model, see Dimitris Xenos, "The European Unified Patent Court: Assessment and Implications of the Federalisation of the Patent System in Europe", (2013) 10:2 SCRIPTed, <http://script-ed.org/wpcontent/uploads/2013/08/xenos.pdf >, pp. 246, 277, at p. 275. 
occurred or may occur». According to the interpretation made by the Court of Justice of the parallel provision in article 5(3) of the Brussels I Regulation - article 7(2) of the Brussels I bis Regulation -, the wording «place where the harmful event occurred or may occur» covers both the place where the damage occurred and the place of the event giving rise to it, so that the defendant may be sued, at the option of the applicant, in the courts for either of those places ${ }^{33}$. Furthermore, in relation to the application of those two connecting factors, the Court has held that, by contrast with the limited scope of jurisdiction of the courts of the place where the damage occurs ${ }^{34}$, the courts of the place where the event giving rise to the damage occurred have jurisdiction to award damages for all of the harm caused by the infringement ${ }^{35}$.

Therefore, if the place where the event giving rise to an infringement of a European patent that also produces damages outside the Union is located in a Contracting State to the UPC Agreement, it seems that the UPC could have unrestricted jurisdiction over the whole infringement on the basis of article 7(2) Brussels I bis Regulation without the need of a supplementary rule. Notwithstanding this, the possibility to distinguish between the place of the event and the place where the damage occurs can be regarded as exceptional with respect to patent infringements ${ }^{36}$.

The typical situations are those where the events giving rise to the damage inside and outside the EU as a result of the infringement of a European patent are located in several States. According to the case law of the ECJ those cases have to be deemed as involving different infringements. As regards States that participate in the Munich Convention ${ }^{37}$ but are non-contracting States to the UPC, it seems relevant to recall that the Court of Justice considered that it is clear from articles 2(2) and 64(1) of the Munich Convention that a European patent continues to be governed by the national law of each of the

${ }^{33}$ ECJ Judgment of 16 May 2013, C-228/11, Melzer, para. 25; ECJ Judgment of 19 April 2012, C-523/10, Wintersteiger, para. 19; ECJ Judgment of 3 October 2013, C-170/12, Pinckney, para. 26; and ECJ Judgment of 5 June 2014, C-360/12, Coty, para. 46.

34 ECJ Judgment of 19 April 2012, C-523/10, Wintersteiger, para. 25; ECJ Judgment of 3 October 2013, C-170/12, Pinckney, para. 37.

35 See ECJ Judgment of 7 March 1995, C-68/93, Shevill, para. 33; ECJ Judgment of 25 October 2010, C-509/09 and C-161/10, eDate Advertising and Martínez, para 42; and on the determination of the place where the event giving rise to the damage occurred, ECJ Judgment of 19 April 2012, C-523/10, Wintersteiger, paras. 30 et seq

36 Wolfgang von Meibom and Johann Pitz, "Cross-Border Injunctions in International Patent Infringement Proceedings”, EIPR, vol. 19, 1997, pp. 469-478, p. 470.

${ }^{37}$ Convention on the Grant of European Patents (European Patent Convention) of 5 October 1973 as revised by the Act revising Article 63 EPC of 17 December 1991 and the Act revising the EPC of 29 November 2000. 
States for which it has been granted, and in accordance with article 64(3) of the Convention, any action for infringement of a European patent must be examined in the light of the relevant national law in force in each of the States for which it has been granted ${ }^{38}$. Although the wording of article 71(b)(3) refers to "an infringement", it can be established that proceedings concerning at the same time the infringement of a European patent within the Union and outside the Union cover in practice different infringements. In these circumstances, the extension of the jurisdiction of the UPC to adjudicate a patent infringement outside the EU on the basis of an asset-related supplementary ground of jurisdiction, where the UPC has no jurisdiction under Chapter II of the Brussels I bis Regulation, seems controversial.

Additionally, the connecting factor established in the new article 71(b)(3) of the Brussels I bis Regulation seems questionable, in particular with regard to disputes concerning patent infringements. The final text of the Regulation is more restrictive than the Commission proposal, since it allows jurisdiction to be established if property belonging to the defendant is located in a Member State party to the UPC Agreement and the dispute has a sufficient connection with that Member State. Notwithstanding this, recourse to such connecting factor in the terms of Regulation (EU) $n^{0} 542 / 2014$ seems to raise reasonable objections.

A forum based on the location of property may be appropriate for some disputes. In fact the 2010 Commission Proposal to amend Regulation No 44/200139 intended to add a new special jurisdiction rule in the Regulation granting jurisdiction to the courts of the place where the property is situated as regards rights in rem or possession in moveable property. However, that special forum was finally not included. Additionally, article 71(b)(3) is not based on that provision but on the failed subsidiary jurisdiction rule envisaged in the 2010 Proposal concerning jurisdiction over third State defendants. The need for additional grounds of jurisdiction with respect to such defendants, including a more flexible approach as to the functioning of the jurisdiction rules and the creation of a forum necessitatis (as envisaged in the 2010 Commission Proposal to reform the Brussels I Regulation), could be appropriate when addressing the jurisdiction over

${ }^{38}$ ECJ Judgment of 13 July 2006, C-593/03, Roche Nederland, paras. 27 et seq; see Annette Kur, “A Farewell to Cross-Border Injunctions? The ECJ Decisions GAT v LuK and Roche Nederland v. Primus and Goldenberg”, IIC, 37 (2006), p. 844-855.

${ }^{39}$ Proposal for a Regulation on jurisdiction and the recognition and enforcement of judgments in civil and commercial matters (Recast), COM(2010) 748 final of 14 December 2010 
disputes involving defendants domiciled outside the $\mathrm{EU}^{40}$. However, article 71(b)(3) does not fit that purpose.

Although in some Member States there are rules that enable jurisdiction to be founded on the presence within the forum country of assets belonging to the defendant $^{41}$, recourse to such a connecting factor seems particularly questionable to grant jurisdiction to the UPC over infringements of European patents in third States ${ }^{42}$. It should be recalled that this subsidiary rule of jurisdiction only applies to situations where the UPC lacks jurisdiction over such infringements pursuant to the grounds established in Chapter II of the Regulation, and does not refer to tangible property that is directly related to the infringement action. The location of property directly related to an infringement, such as infringing articles - including goods seized as a control measure - would be relevant to grant jurisdiction under article 7(2) of the Brussels I bis Regulation. Also under Chapter II of the Regulation -and the new article 71(b)(2)provisional measures can be adopted, for instance, against goods that have to be disposed of outside the channels of commerce or destroyed ${ }^{43}$. Granting additional jurisdiction to the UPC over the infringement of third-State (although European) patents on the basis that the defendant has assets unrelated to the infringement in a Contracting State to the UPC, should generally be regarded not only as an exorbitant ground of jurisdiction but also as inappropriate for disputes over the infringement of patent rights. This conclusion seems supported by the sets of principles concerning jurisdiction in intellectual property disputes drafted in recent years, in particular by the European MaxPlanck Group on Conflict of Laws in Intellectual Property (CLIP) ${ }^{44}$ the American Law Institute ${ }^{45}$.

\footnotetext{
${ }^{40}$ See article 26 of the Commission Proposal, COM(2010) 748 final.

${ }^{41}$ For instance, see on paragraph 23 of the German Civil Procedure Code, Haimo Schack, Internationales Zivilverfahrensrecht, $5^{\text {th }}$ ed., Munich, C.H. Beck, 2010, p. 131-135.

${ }^{42}$ Although in other EU Member States the presence within the forum of property belonging to the defendant may also be one of the traditional bases of jurisdiction under national law, it has not been applied to cases of infringement of foreign intellectual property rights, see James J. Fawcett and Paul Torremans, Intellectual... cit., at p. 282.

${ }^{43}$ Christian Heinze, Einstweiliger Rechtsschutz im europäischen Immterialgüterrecht, Tübingen, Mohr Siebeck, 2008, pp. 188-260.

${ }^{44}$ European Max-Planck Group on Conflict of Laws in Intellectual Property (CLIP) "Principles on Conflict of Laws in Intellectual Property", 1 December 2011, published in European Max-Planck Group on Conflict of Laws in Intellectual Property, Conflict of Laws in Intellectual Property (The CLIP Principles and Commentary), Oxford, 2013, pp. 1-22.

${ }^{45}$ The American Law Institute, ALI Principles - Intellectual Property: Principles Governing Jurisdiction, Choice of Law, and Judgments in Transnational Disputes, Chestnut, ALI, 2008.
} 
A jurisdiction forum based on the presence in the forum State of property belonging to the defendant unrelated to the dispute, is widely regarded as inappropriate in the context of intellectual property litigation. In particular, the European CLIP Principles do not envisage the mere location of property belonging to the defendant as a ground of jurisdiction ${ }^{46}$. More explicit in this respect are the ALI Principles. Section 207 ALI Principles provides a list of «Insufficient Grounds for Jurisdiction over Transnational Disputes» and the first connection that is regarded as insufficient is «the presence in that State of tangible property belonging to the defendant, except when the dispute is directly related to that property» ${ }^{47}$. A similar approach prevails in the model provisions concerning international jurisdiction over intellectual property litigation drafted in other regions of the world ${ }^{48}$.

The exorbitant nature of the jurisdiction ground inserted in the Regulation is reinforced by the view that a sufficient connection between the asset based forum and the dispute may be established for the purposes of the new Article 71b(3) Brussels I bis Regulation when the claimant is domiciled there, as stated in Recital 7 of Regulation (EU) $n^{\circ} 542 / 2014$. Additionally, such exorbitant ground of jurisdiction is intended to be applied in circumstances in which the country where the patent is infringed (and possibly where the defendant is also domiciled) is a Contracting State to the Munich Convention that has a particularly closer connection with the dispute that relates to a patent infringement in its territory. It is to be noted that if the event giving rise to the alleged infringement is located in a Contracting State to the UPC - and this could be particularly helpful in relation to evidence -, the UPC would normally be competent to adjudicate the infringement on the basis of Article 7(2) of the Brussels I bis Regulation.

${ }^{46}$ See European Max-Planck Group on Conflict of Laws in Intellectual Property, Conflict... cit., at pp. 56-195, discussing Part 2 on Jurisdiction of the CLIP Principles; Christian Heinze, "A Framework for International Enforcement of Territorial Rights: The CLIP Principles on Jurisdiction", Jürgen Basedow, Toshiyuki Kono and Axel Metzger (eds.), Intellectual Property in the Global Arena Jurisdiction, Applicable Law, and the Recognition of Judgments in Europe, Japan and the US, Tübingen, Mohr Siebeck, 2010, pp. 53-77; and Annette Kur and Benedetta Ubertazzi, "The ALI Principles and the CLIP Project: A Comparison", Stefania Bariatti (ed.), Litigating Intellectual Property Rights Disputes Cross-border: EU Regulations, ALI Principles, CLIP Project, Milan, CEDAM, 2010, pp. 89-147.

47 See The American Law Institute, ALI Principles... cit., comment b) to Section 207. The consequence of relying on such a ground of jurisdiction is that the ensuing judgment should not be recognized abroad, cf. François Dessemontet, "The ALI Principles: Intellectual Property in Transborder Litigation”, Jürgen Basedow, Toshiyuki Kono and Axel Metzger (eds.), Intellectual... cit., pp. 31-48, at p. 37.

48 See Paulius Jurčys, “International Jurisdiction in Intellectural Property Disputes", JIPITEC, Vol. 3 (2012), pp. 174-226, at p. 177. 
In the typical situations, a judgment given by the UPC based on the supplementary ground of jurisdiction should not be recognized or enforced in the non EU country of infringement, in particular since the judgment shall not comply with the standard of review of the jurisdiction of the rendering court ${ }^{49}$. However, the location of assets of the defendant in a Member State of the UPC Agreement and the application of the relevant provisions of the Brussels I bis Regulation will usually make possible the enforcement of a monetary judgment outside that country of infringement.

\section{Mutual recognition and enforcement of judgments}

\section{Scope of the Regulation}

Regulation (EU) $n^{\circ} 542 / 2014$ inserts a new article 71(d) in the Brussels I bis Regulation concerning mutual recognition and enforcement of judgments between, on the one hand, the Contracting States to the UPC Agreement and the Member States to the Brussels I bis Regulation which are not a party to the UPC Agreement, on the other. As regards this subject matter, the final text of the Regulation does not deviate significantly from the Commission proposal. In accordance with the general scope of application of the Brussels I bis Regulation, the provisions of Regulation (EU) $\mathrm{n}^{\mathrm{o}}$ $542 / 2014$ do not deal with the recognition and enforcement of judgments rendered in third States.

Moreover, concerning the situation within the Contracting States to the UPC Agreement, it is determinative that pursuant to Article 82 of the UPC Agreement, the decisions and orders of the UPC shall be enforceable in any Contracting Member State. Therefore, recognition or declaration of enforceability of such decisions and orders are not necessary in the Member States parties to the UPC Agreement. The new article 71(d)(2) inserted in the Brussels I bis Regulation confirms that the Regulation shall not apply to the recognition and enforcement of judgments given by a common court where such recognition and enforcement is sought in a Member State party to the Agreement establishing the common court. Since by virtue of article 82 of the UPC Agreement, the

${ }^{49}$ Cf. Pedro A. De Miguel Asensio, "Recognition and Enforcement of Judgments in Intellectual Property Litigation: The CLIP Principles", Jürgen Basedow, Toshiyuki Kono and Axel Metzger (eds.), Intellectual... cit., pp. 239-292, at p. 274. 
decisions and orders of the UPC shall be enforceable in any Contracting Member State of the Agreement, the effectiveness within Contracting Member States of such judgments is not subject to the rules on recognition and enforcement of foreign judgments. However, UPC Agreement does not harmonize national enforcement procedures. ${ }^{50}$

According to Article 34 of the UPC Agreement, the territorial scope of decisions of the UPC shall cover, in the case of a European patent, the territory of those Contracting Member States for which the European patent has effect. Hence, disputes relating only to European patents with unitary effect should not cover the territory of EU Member States where the European patent was validated but that stay outside the UPC system. It is worth recalling that, as a general rule, the territorial scope of a prohibition against infringement of a patent is to be determined both by reference to the territorial jurisdiction of the court hearing the case and to the territorial extent of the proprietor's exclusive right which is adversely affected by the infringement ${ }^{51}$.

\section{Grounds for non-recognition}

Article $71(\mathrm{~d})$ is the new provision on recognition and enforcement of judgments inserted in the Brussels I bis Regulation by virtue of Regulation (EU) $n^{\circ} 542 / 2014$. It establishes that the provisions of the Brussels I bis Regulation apply to the recognition and enforcement of judgments given by the UPC which are to be recognised and enforced in a Member State not party to the UPC Agreement. Therefore, the provisions on recognition and enforcement of the Regulation shall be applicable to judgments rendered by the UPC, including those adopted on the basis of the special jurisdiction rule for defendants not domiciled in a Member State.

The grounds for refusal of recognition or enforcement are set out in article 45 Brussels I bis Regulation. Those grounds apply in addition to the grounds for refusal or of suspension of enforcement under the law of the Member State addressed for judgments rendered by its own courts. The grounds to refuse enforcement under Regulation 1215/2012 are the same provided for by articles 34 and 35 Regulation

\footnotetext{
${ }^{50}$ Roberto Baratta, “The Unified Patent Court - What is the 'common' trait about?", in Costanza Honorati (ed.), Luci... cit., pp. 101-117, at p. 111.

${ }^{51}$ ECJ Judgment of 12 April 2011, C-235/09, DHL Express, para. 33.
} 
44/2001 to deny exequatur: public policy; respect of the rights of defence of the defaulting defendant; incompatibility between judgments; and very limited verification of the jurisdiction of the rendering court ${ }^{52}$. Procedural public policy as a ground to refuse recognition and enforcement under article 45 Brussels I bis Regulation will allow courts of the EU Member States that are not Contracting Parties to the UPC Agreement to check that judgments rendered by the UPC meet the fundamental principles of procedural fairness, including equal treatment and reasonable opportunity for litigants to assert or defend their rights and avoidance of any kind of illegitimate discrimination; the right to be heard; or a reasoned explanation of the essential basis of the judgment $t^{53}$.

Under article 45 Brussels I bis Regulation the international jurisdiction of the court of the Member State of origin is reviewed only exceptionally, in particular to ensure that the foreign judgment does not conflict with the provisions on exclusive jurisdiction. In this connection it is noteworthy that a judgment by the UPC holding the invalidity of a European bundle patent cannot encompass the territory of an EU Member State which is not party to the UPC Agreement. This same standard should be applicable to the recognition and enforcement of judgments rendered by the UPC in a Member State of the Regulation that is not a party to the UPC. The scope of the exclusive jurisdiction rule of article 24(4) Brussels I bis Regulation is also decisive in the application of article 45. It is to be recalled that exclusive jurisdiction is granted under that provision irrespective of whether the validity or registration issue is raised by way of an action or as a defence.

However, it is noteworthy that the general approach in this regard of the Brussels I bis Regulation is related to the fact that the Regulation unifies the jurisdiction rules applicable by the courts of all Member States. Such a unification is lacking with respect to defendants not domiciled in a Member State (article 6 Brussels I bis Regulation). In this respect, the concerns raised with respect to the supplementary jurisdiction rule based on the location of property of the defendant in a Member States party to the UPC Agreement are of particular importance in the light of the new article 71(d), given the potentially exorbitant reach of that rule of jurisdiction and the restrictive standard of

\footnotetext{
52 Pedro A. De Miguel Asensio, "Recognition... cit., at pp. 267 et seq.

${ }^{53}$ See Mark Bosshard, 'L’entrata... cit., p. 227.
} 
review of the jurisdiction of the court of origin applicable under article 45(1)(e) Brussels I bis Regulation.

Furthermore, the new article 71(d)(1)(b) confirms that the Brussels I bis Regulation is also to be applied to judgments given by the courts of a Member State not party to the UPC Agreement which are to be recognised and enforced in a Member State party to that Agreement. The latter provision could be regarded as redundant, since the application of the Regulation to those situations seems undisputed in the light of the scope of the Regulation before the adoption of Regulation (EU) $n^{0} 542 / 2014$.

\section{Methods of enforcement}

Article 82 of the UPC Agreement establishes that the enforcement procedures shall be governed by the law of the Contracting Member State where the enforcement takes place, and that any decision of the UPC shall be enforced under the same conditions as a decision given in the Contracting Member State where the enforcement takes place. This is consistent with the idea that since decisions and orders of the UPC are enforceable in all Contracting States to the UPC Agreement, they are incorporated in the respective legal orders and they have to be treated for enforcement purposes as judgments of the State were enforcement is sought. Moreover, article 82(4) UPC Agreement provides for a specific enforcement measure.

These provisions are intended to regulate enforcement proceedings but not the recognition and enforcement of foreign judgments. In fact, Member States of the EU lack competence to conclude international conventions on recognition and enforcement of foreign judgments concerning patent claims covered by the Brussels I Regulation.

Article 82(4) of the UPC Agreement refers to a specific method of enforcement by establishing that if a party does not comply with the terms of an order of the UPC, that party may be sanctioned with a recurring penalty payment payable to the Court. In relation to the recognition and enforcement of such measures in a Member State not party to the UPC Agreement, it is noteworthy that, with respect to the similar enforcement measure established in Paragraph 890 of the German Civil Procedure Code, the ECJ has already established that the Brussels I Regulation applies to the recognition and enforcement of a decision of a court or tribunal that contains an order to 
pay a fine in order to ensure compliance with a judgment given in a civil and commercial matter ${ }^{54}$. Therefore, the fact that the penalty is to be payable to the Court does not affect its inclusion in the scope of the Brussels I Regulation which is determined by the nature of the subjective right that the enforcement measure serves to $\operatorname{protect}^{55}$.

Moreover, the case-law of the ECJ has already established that where the national law of the requested Member State does not contain a coercive measure similar to a periodic penalty payment to ensure compliance with a prohibition against further infringement, the objective pursued by that measure must be attained by the court of the requested Member State by having recourse to the relevant provisions of its national law which are such as to ensure that the prohibition is complied with in an equivalent manner ${ }^{56}$. Article 54 of the Brussels I bis Regulation addresses this issue by imposing, to the extent possible, the adaptation of the measure or order unknown in the law of the requested State to a measure or an order known in that law that has equivalent effects and which pursues similar aims and interests. Furthermore, article 54(2) of the Brussels I bis Regulation grants any party the possibility to challenge such adaptation before a court.

\section{Conclusion}

Regulation (EU) 542/2014 extends the jurisdiction rules of the Brussels I bis Regulation to defendants not domiciled in a Member State for matters which fall within the competence of the UPC, and complete those rules by creating an additional subsidiary forum for disputes involving such defendants. The new forum enables the UPC to hear disputes involving defendants from third States relating to an infringement of a European patent giving rise to damage as well inside as outside the Union. Granting jurisdiction to the UPC to adjudicate infringements outside the territory of the Contracting States to the UPC on the basis of an asset-related supplementary ground of jurisdiction, where the UPC has no jurisdiction under Chapter II of the Brussels I bis

\footnotetext{
${ }^{54}$ See Costanza Honorati, Il riconoscimento delle decisioni in materia di proprietà intellettuale, in Andrea Giussani (ed.), Il processo industriale, Torino, G. Giappichelli Editore, 2012, p. 481-523, at pp. 511-513.

${ }^{55}$ ECJ Judgment of 18 October 2011, C-406/09, Realchemie Nederland, para. 42.

${ }^{56}$ ECJ Judgment of 12 April 2011 C-235/09, DHL Express, para 56.
} 
Regulation, seems questionable. It allows the UPC to adjudicate claims concerning the infringement of European patents in countries not participating in the UPC Agreement in circumstances in which such a broadening of the international jurisdiction of the UPC is not appropriate and may undermine the position and interests of those other European countries affected. While the rationale of such a questionable rule seems to be facilitating the single adjudication of pan-European claims before the UPC with a view to promoting the new court as a major forum for cross-border disputes, from a broader international perspective it can be noted that the implementation of the UPC Agreement could also be a source of fragmentation in cases where the defendant is domiciled in a Member State, since the new court is only established for the settlement of disputes relating to European patents and European patents with unitary effect. 